\title{
Relationship between oral hygiene and gingival condition of Malaysian students
}

\author{
Muhammad Arif Mohd Marsin*, Yanti Rusyanti*, Ina Hendiani* \\ *Department of Periodontics Faculty of Dentistry Universitas Padjadjaran, Indonesia
}

\section{ABSTRACT}

The primary etiologic agent of gingival disease was dental plaque which also involving the oral hygiene. The oral hygiene can be affected by individuals knowledge, attitude, practice, environment, and others. The purpose of this study was to assess the relationship between oral hygiene and gingival condition of Malaysian students. The type of this study was cross-sectional study. The study was conducted on a total of 66 Malaysian students. The data were collected by using an examination form and clinical examination using the Loe \& Sillness gingival index followed by the Loe \& Sillness plaque index. The results showed that $100 \%$ of students have gingivitis with the gingival index average of 1.25 and the plaque index average of 1.85. The relationship of gingival and plaque index was analyzed by using Spearman's Rank Correlation Coefficient test, and the score was 0.623 . It is concluded that the oral hygiene status of Malaysian students was in the fair category, and all Malaysian students had a moderate gingivitis. Also, there was a relationship between the oral hygiene status and gingival condition of Malaysian students.

Keywords: Oral hygiene, gingival condition, plaque index, gingival index, Malaysian students

\section{INTRODUCTION}

Healthy according to the Law of Health Number 23 Year 1992 was a good state of physic, mental, and social, that allowed each person live a productive life socially and economically. ${ }^{1}$ A healthy adolescents or students live productive socially which means able to run activity such as school or lecture. According to Blum in 1974, one of the factors affecting health is the environment, including education level which indirectly affects health. Students all over the world including Malaysian students studying in Indonesia were also affected by this factor. ${ }^{2} \mathrm{~A}$ good oral health is a state of being free from any diseases and disorders affecting the oral cavity. Poor oral hygiene is one of the factors affecting the oral health. Poor management of oral hygiene care such as toothbrushing and dental flossing will cause plaque accumulation that leads to gingival inflammation (gingivitis).

Gingivitis is an inflammatory response of the gingival without destruction of the supporting tissue that appears red in color, lost of stippling, swollen, and bleeding on probing. ${ }^{3}$ One of the gingivitis factors is an accumulation of the dental plaque. Plaque is a tenacious microbial community which develops on the soft and hard-tissue surfaces of the tooth, consisted of the viable, dead, and dying bacteria along with

Corresponding author: Muhammad Arif Mohd M, Department of Periodontics Faculty of Dentistry Universitas Padjadjaran, Jl. Sekeloa Selatan No.1, Bandung, Indonesia, 40132. Ph./Fax:+6222-2504985/2532805 
their extracellular product, together with host compounds mainly derived from saliva. ${ }^{4}$ Clinically, plaque was defined as structured, resilient, yellowgrayish substances that adhere tenaciously to the intraoral hard surfaces, including the removable and fixed restorations. ${ }^{5}$

Many studies have already proved the relationship between the plaque and the occurrence of the gingivitis. The cause and effect of the relationship between plaque and gingival inflammation were also demonstrated in a classic study conducted by Loe et al. The study was abstaining from all forms of oral hygiene for several days and found the development of gingivitis. After one week of resuming the oral hygiene forms, gingival inflammations were resolved. It can concluded that gingival inflammation was an essential product of bacterial plaque related to the oral hygiene condition. ${ }^{5}$ The purpose of this study was to assess the relationship between oral hygiene and gingival condition of Malaysian students.

\section{METHODS}

A sample of 66 students aged 17-25 years old was selected from the population of Malaysian students in Universitas Padjadjaran. A mouth mirror, a dental explorer, probe, tweezers, alcohol $70 \%$, a disposable cup, cotton, gloves, mask, questionnaires, torchlight, and stationery were used in this study.

The Loe \& Silness Gingival Index and Plaque Index were used as a measurement in this study. To assess the gingival index, samples categorized in criteria such as follows: healthy (0); mild gingivitis (1); moderate gingivitis (2); and severe gingivitis (3). To assess the plaque index, samples categorized in criteria such as follows: good (01.0); fair (1.1-2.0); and poor (2.1-3.0).

Firstly, samples will be given questionnaire before proceeding to the clinical examination. After answering the questionnaire, samples were seated towards the light on the chair provided to make the operator examined the teeth clearly. Samples were instructed to gargle with water. The measurement of the gingival scoring was performed using the Loe \& Sillness Gingival Index, and the measurement of the oral hygiene (plaque scoring) was performed using the Loe \& Sillness Plaque Index. After all procedures were conducted, all samples were instructed to gargle with water again and leave.

\section{RESULTS}

Based on the statistic analysis using Spearman's rank correlation test, the Spearman's rank correlation coefficient was 0.623 . The value

Table 1. Samples Characteristic

\begin{tabular}{lcccccccccc}
\hline \multirow{1}{*}{ Faculty } & \multicolumn{1}{c}{ Age } & \multicolumn{7}{c}{ Gender } & Sample & $\%$ \\
\cline { 2 - 8 } & 18 & 19 & 20 & 21 & 22 & 23 & M & F & & \\
\hline Medicine & 1 & 9 & 27 & 6 & & 1 & 22 & 22 & 44 & 66.67 \\
Dentistry & 2 & 4 & 3 & 1 & & & 5 & 5 & 10 & 15.15 \\
Pharmacy & & 1 & 1 & 4 & 2 & 4 & 6 & 6 & 12 & 18.18 \\
\hline Total & 3 & 14 & 31 & 11 & 2 & 5 & 33 & 33 & 66 & 100.00 \\
\hline
\end{tabular}

Table 2. Plaque Index and Gingival Index of Malaysian Students

\begin{tabular}{cccc}
\hline Index & Category & F & $\%$ \\
\hline \multirow{3}{*}{ Plaque Index } & Good & 2 & 3.0 \\
& Fair & 53 & 80.3 \\
& Poor & 11 & 16.7 \\
& Total & 66 & 100 \\
Gingival Index & Mild & 12 & 18.2 \\
& Moderate & 54 & 81.8 \\
& Severe & 0 & 0.0 \\
& Total & 66 & 100 \\
\hline
\end{tabular}


Table 3. Average of Plaque Index and Gingival Index based on faculty

\begin{tabular}{cccc}
\hline Faculty & Sample & Plaque index & Gingival index \\
\hline Medicine & 44 & 1.757 & 1.186 \\
Dentistry & 10 & 1.797 & 1.242 \\
Pharmacy & 12 & 1.992 & 1.316 \\
\hline
\end{tabular}

Table 4. Spearman's rank correlation coefficient

\begin{tabular}{|c|c|c|c|}
\hline \multicolumn{4}{|c|}{ Correlations } \\
\hline & & $\begin{array}{l}\text { Oral } \\
\text { Hygine }\end{array}$ & $\begin{array}{l}\text { Gingival } \\
\text { Condition }\end{array}$ \\
\hline \multirow{3}{*}{$\begin{array}{l}\text { Oral } \\
\text { Hygine }\end{array}$} & Correlation Coefficient & 1.000 & $.623^{* *}$ \\
\hline & Sig. (2-tailed) & & .000 \\
\hline & $\mathrm{N}$ & 66 & 66 \\
\hline \multirow{3}{*}{$\begin{array}{l}\text { Gingival } \\
\text { Condition }\end{array}$} & Correlation Coefficient & $.623^{* *}$ & 1.000 \\
\hline & Sig. (2-tailed) & .000 & \\
\hline & $\mathrm{N}$ & 66 & 66 \\
\hline
\end{tabular}

** Correlation is significant at the 0.01 level (2-tailed)

Table 5. Guilford criteria for Spearman's rank

\begin{tabular}{cc}
\hline Coefficient Interval & Correlation Level \\
\hline $0.000-0.199$ & Very low \\
$0.200-0.399$ & Low but definite \\
$0.400-0.699$ & Significant \\
$0.700-0.899$ & Strong \\
$0.900-1.00$ & Very high, Very strong \\
\hline
\end{tabular}

given was interpreted by using the Guilford Criteria. $^{5}$

Based on the results from Table 1, Table 2, Table 3, Table 4, and Table 5, it was known that oral hygiene and gingival condition have a significant relationship. The correlation measurement gives a positive $(+)$ result which means that there was a direct relationship.

\section{DISCUSSION}

Based on the results from this study, the average value of the plaque index was 1.85 , with as much as $3.0 \%$ of the students were in the good category, $16.7 \%$ of students in the poor category, and the highest percent-age (80.3\%) of the students was in the fair category. The amounts of plaque accumulation showed the level of the student's oral hygiene. The majority of the students did not know the true definition of plaque. As much as $42.4 \%$ of them answered plaque is a hard deposit, and only $25.8 \%$ of them answered plaque is a soft deposit. As much as $50 \%$ of dentistry students answered plaque is a stain on the tooth. It can assumed that the students were not receiving any formal or intensive dental health education. Therefore, the dental knowledge of the 2011 batch of Malaysian students in Universitas Padjadjaran was similar even though coming from different faculty.

Education only was not enough to motivate a person change. Attitude and behaviour are both need-ed to influence the change. Research conducted by Aryanto towards the 2001 batch of undergraduate students of Universitas Padjadjaran showed that their oral hygiene status was 2.95 (using $\mathrm{OHI}-\mathrm{S}$ ) which was categorized as fair, but in the borderline with the poor category. Behaviour related to knowledge, and attitude is the response of knowledge, but in reality, the environment stimulates behaviour more than knowledge and attitude. In other words, individual behaviour was not always based on the knowledge and attitude. ${ }^{1}$ Environment factors such as family and close friends were also influencing the oral hygiene behaviour. As a medical student, negative influence from the environment will affect the oral health care.

The average value of the gingival index was 1.25 , with as much as $81.8 \%$ of students were in the fair category, $18.2 \%$ of students in the good category, and there was no student $(0 \%)$ in the poor category. The gingival condition measured by the sign of inflammation, redness, and bleeding on probing. Most students could link the signs of gum bleeding with inflamed gum $(57.6 \%)$ which meant that they knew the sign of gingivitis. In a survey conducted in Malaysia, about $9.8 \%$ of the subjects (total $n=10,891$ ) have healthy gingiva (Malaysian National Oral Health Survey, 2000). Thus showing that gingivitis was common among Ma-laysians whether they realize it or not. Research conducted by Sari towards the 2001 batch of undergraduate students of Universitas Padjadjaran showed that $100 \%$ of the students had a moderate gingivitis. ${ }^{7}$ From this study, it can assumed that the prevalence of gingivitis among university students between the two coun-tries (Malaysia and Indonesia) were similar. 
Furthermore, as much as $45.5 \%$ of them knew how to prevent the inflamed gum with toothbrushing and dental floss. Despite most of them knowing the inflamed gum signs and prevention, all of them still had gingivitis. This condition may be caused by their improper oral care method or by other etiologies such as irregular tooth arrangement, hormone, and stress level. The ir-regularity tooth arrangement will make plaque control more difficult. Hence it will increase the rate of plaque accumulation. Hormone, especially for female, can affect the periodontal tissues directly, modify the tissue response towards the local factors, and produce anatomic changes in the gingival that may in-crease the plaque accumulation. ${ }^{5}$

On the attitude regarding dental check-up, most of them (43.9\%) go to the dentist only when feeling pain, and only $19.7 \%$ do a regular dental check-up. About $42.5 \%$ of the students have visited the dentist in the past six months to two years. It may caused by unavailability of the dental health program at school or a mandatory health test as a higher education requirement. It is generally accepted that dental visit is not a popular health-related activity for adults, especially for Malaysian adults. Malaysian National Oral Health Survey of Adults in 2000 reported that only about $60 \%$ of the subject (total $n=10,891$ ) with oral problems perceived the needs to see the dentist. ${ }^{8}$ The reasons for not seeking dental treatment consisted of the absence of pain, the lack of seriousness of the problem felt, lack of time, lack of finance to pay for the cost of treatment, and dental fear. The research conducted by Knowles, Ramfjord, and Nabers stated that good prognosis of treatment could achieved when the patient visits at least once in three to sixth months. There-fore, visiting the dentist was an important thing in the oral health care. ${ }^{9}$

This study has indicated that a high percentage of students brush their teeth twice a day, once in the morning and once in the night before bedtime. Some students brushed their teeth more than twice a day, which means they brushed their teeth after every meal. There were also few students who brushed only once a day caused such frequency was felt sufficient enough or they did not care about their oral care. Brushing after every meal is unnecessary to prevent gingivitis considering the time needed for plaque to ma-ture bacteriologically. The best frequency of toothbrushing was twice a day to maintain oral health. ${ }^{10}$ Brushing teeth in the morning and evening fits with most people daily routines and should be the basis for the education of the common people and dental patients. From this study discovered that the oral hygiene status of the students still not reaching the good category, even though many of them were brushing their teeth twice a day. This condition may caused by to the lack of optimal brushing quality. Brushing teeth twice a day especially before bedtime was recommended according to Grant (1979) because plaque will start to accumulate within several minutes during bedtime. Hence it was important to brush the teeth to prevent plaque accumulation. However, the frequency of toothbrushing was not sufficient enough to maintain the oral health, because according to Carranza, the toothbrushing quality was more important than the quantity. ${ }^{9}$ Fluoride toothpaste is a major source of fluoride exposure for caries prevention. It will inhibit demineraliza-tion and enhance remineralization during the repeated cycles of demineralization-remineralization in the early stages of the caries process. Fluoride also inhibits glycolysis, the process of the metabolism of fer-mentable carbohydrate by cariogenic bacteria and producing acid. ${ }^{10}$

The recommendation of oral care instrument use such as dental floss and mouthwash were rare; about $50 \%$ of students did not use such instruments. Supplemental oral care instrument such as interdental cleaning aids and mouthwash is also needed especially for individuals with irregular tooth arrangement. It is important to clean the interdental areas to reduce the plaque accumulation. This condition could be caused by the lack of finance or lack of dental health education.

Based on the statistic analysis results, there was a relationship between the oral hygiene and gingival condition. This result was consistent with the study conducted by Schroeder and Ribeiro that reported there was a positive correlation between the presence of plaque and gum inflammation stages. ${ }^{10}$

The study was also consistent with the research by Loe et al. regarding the relationship between plaque and gingivitis development. Gingivitis appeared after oral hygiene negligence 
about 8 to 21 days. The bacterial plaque was the primary etiologic agent of gingivitis. ${ }^{11}$ The study proved that oral hygiene influenced the gingival inflammation. If a person had a good oral hygiene, other etiologic factors such as tooth crowding would not contribute to the development of gingivitis. Many studies have proved the relationship between plaque and gingivitis. Study conducted by Suarsih on State Elementary School of Bandung Regency students has also proved the role of plaque towards gingivitis. ${ }^{12}$ Development of gingivitis required the presence of plaque which will induce pathologic changes. ${ }^{13}$

Based on the questionnaire, as much as $22.7 \%$ of the students were managed to relates the presence of plaque and gingivitis, but the remaining $78.3 \%$ of the students were failed to relates such matter or even did not know such relationship. Oral hygiene negligence will cause the plaque accumulation. The lack of dental health education, environmental influence, the methods used in plaque control, and the attitude to-wards oral health care, will affect the oral hygiene. It is known that plaque is the main etiology of the occurrence of gingivitis, and the oral hygiene status is determining the plaque accumulation. The poor oral hygiene will increase the chance of gingivitis occurrence. Therefore, it is important to maintain a good oral hygiene through a regular and thorough oral health care. Also, the knowledge regarding the role of plaque and oral hygiene towards gingivitis and the methods of proper oral health care needs to be improved.

\section{CONCLUSION}

The oral hygiene status of Malaysian students was in the fair category, and all Malaysian students had a moderate gingivitis. Also, there was a relationship between the oral hygiene status and gingival condition of Malaysian students.

\section{REFERENCES}

1. Notoatmodjo S. Metodologi penelitian kesehatan. Jakarta: Rineka Cipta; 2003. p. 3-4, 7-11.

2. Blum HL. Planning for Health, Development and Aplication of Social Changes Theory. 1st ed. New York: Human Sciences Press; 1974.

3. Chestnutt IG, Gibson J. Churchill's Pocketbooks: Clinical Dentistry. 3rd ed. London: Churchill Livingstone; 2007. p. 199, 205-8.

4. Samaranayake L. Essential Microbiology for Dentistry. 3rd ed. London: Churchill Livingstone; 2006. p. 261.

5. Newman MG, Takei HH, Carranza FA. Carranza's Clinical Periodontology. 10th ed. Philadelphia: Saunders-Elsevier; 2006. p. 100-5, 115-7, 13743, 325, 543.

6. Rakhmat J. Metode Penelitian Komunikasi: Dilengkapi Contoh Analisis Statistik. Bandung: Rosda Karya; 2003. p. 82.

7. Sari IA. Gambaran klinis kondisi gusi siswa tunagrahita dewasa muda SLB-C Di Kota Bandung Tahun 2006 [minor thesis]. Bandung: Unpad; 2007.

8. Zainal-Abidin Z, Said SM, Samah ISA, Yusoff MYAM. Oral health awareness and status among universiti kebangsaan malaysia first year dental students. J Sains Kesihatan Malay. 2005;3(1):1-16.

9. Aryanto $M$. Status kebersihan mulut pada mahasiswa S1 angkatan 2001 Universitas Padjadjaran Bandung [minor thesis]. Bandung: Unpad; 2003.

10. Burt BA, Eklund SA. Dentistry, Dental Practice, and The Community. 6th ed. Philadelphia: Saunders-Elsevier; 2005. p. 395-402.

11. Schroeder MDS, Ribeiro GLU. Evaluation of periodontal index of gingival and plaque with dental crowding in development of gingivitis in children and adolescents. RSBO. 2004;1(1):1721.

12. Suarsih S. Hubungan antara plak dengan kondisi gusi pada pelajar SLTP negeri usia 12-14 Tahun Di Kabupaten Sumedang [minor thesis]. Bandung: Unpad; 2003.

13. Research, Science, and Therapy Committee of The American Academy of Periodontology. The Pathogenesis of periodontal disease. J Periodontol. 1999 Apr;70(4):457-70

14. Burt B, Research, Science and Therapy Committee of the American Academy of Periodontology. Position paper: epidemiology of periodontal diseases. J Periodontol. 2005 Aug;76(8):1406-19. 